\title{
Formulation of quality fish feeds from indigenous raw materials and their effects on growth and maturity of Mystus gulio
}

\author{
M. Begum, H.K. Pal, M.A. Islam and M.J. Alam
}

Bangladesh Fisheries Research Institute, Brackishwater Station, Paikgacha, Khulna-9280.

\begin{abstract}
An experiment was conducted for 140 days in earthen ponds to evaluate the effect of three dietary protein levels on the growth and maturity of bagrid catfish Mystus gulio. Three different iso-caloric feeds containing $30 \%, 35 \%$ and $40 \%$ dietary protein levels were prepared from indigenous fish feed ingredients and were fed to Mystus gulio at the rate of $5 \%$ of total body weight of the fish. The overall growth of Mystus gulio fed with feeds of different levels of dietary protein was found to increase with the increase of dietary protein levels in the feed. The gonadosomatic index (GSI) values of both male and female were higher in Feed-C (40\% protein) compared to the Feed-A (30\%) and Feed-B (35\%). There was significant differences $(P<0.05)$ between the gonadosomatic index values of Mystus gulio fed on different dietary protein levels. Statistical analysis showed that the feed at a level of $40 \%$ protein was significantly different from other feeds and most effective in changing the growth and maturity of $M$. gulio.
\end{abstract}

Keywords: Formulated feed, Maturity, Mystus gulio

\section{Introduction}

Mystus gulio, locally known as nona tengra, is a euryhaline estuarine catfish commonly occurring in coastal waters of Bangladesh. The species feed and thrive well in low salinity, and the salinity exceeds $10 \%$, they migrate into waters of low salinity (Pandian, 1966). This species is supporting the coastal fisheries to a great extent, both in point of commercial and local consumption views. M. gulio has already been trapped and grown as a significant additional harvest in most of traditional coastal shrimp ghers. Due to increasing demand in export market and high price, the increased fishing pressure on this species has been resulting in progressively reduced catch. Therefore, to protect and conserve the natural stock, the potential for seed production and culture of this important brackishwater fin fish in captivity has to be developed. We have many kinds of by-products, natural (of plant and animal origin) as well as from domestic and industrial activities. These locally available indigenous raw materials may serve as important ingredients for the formulation and development of cheaper and quality fish feed. In order to do this, it is necessary to develop the technology for proper formulation and manufacturing of the feeds, assuring the optimum contents of indispensable proteins, lipids, minerals, vitamins, growth promoting substances and energy. Though a lot of works have been done on the biology, the fecundity, induced spawning, spawning behavior and larvae rearing of $M$. gulio (David, 1963; Pandian, 1966; Jhingran and Natarajan, 1969; Kaliyamurthy, 1981; Sarker et al 2002; Alam et al 2006a and 2006b; Islam et al 2007), but no scientific study has been conducted for formulation of the quality feed for $M$. gulio brood rearing. So, the present experiment was designed to formulate quality fish feeds from indigenous raw materials and to investigate their effects on growth and maturity (GSI) of M. gulio. 


\section{Material and Methods}

'A' grade fishmeal, mustard (Brassica sp) oil cake and fine rice bran were collected from local market of Paikgacha, Khulna.Vitamin premix was collected from sales agent of Bangladesh Pharmaceutical Industries Ltd. All the feed ingredients were analyzed to determine its proximate composition i.e. Protein, Lipid, moisture, ash, crude fiber and nitrogen free extract by the AOAC procedure (1980) as shown in Table 1.

Table 1. Proximate composition of feed ingredients (Dry basis)

\begin{tabular}{|l|c|c|c|c|c|c|}
\hline Name of ingredient & $\begin{array}{c}\text { Moisture } \\
(\%)\end{array}$ & $\begin{array}{c}\text { Crude } \\
\text { protein } \\
(\%)\end{array}$ & $\begin{array}{c}\text { Fat } \\
(\%)\end{array}$ & $\begin{array}{c}\text { Ash } \\
(\%)\end{array}$ & $\begin{array}{c}\text { Crude } \\
\text { Fibre } \\
(\%)\end{array}$ & $\begin{array}{c}\text { Nitrogen free extract (\%) } \\
(100-\text { protein \% + ash\% } \\
\text { fibre \%) }\end{array}$ \\
\hline Fish meal & 10.02 & 61.20 & 22.62 & 4.32 & 0.65 & 1.19 \\
\hline Mustard oil cake & 11.50 & 27.00 & 29.15 & 16.60 & 11.48 & 24.87 \\
\hline Rice bran & 10.90 & 10.80 & 20.60 & 5.35 & 15.00 & 37.35 \\
\hline
\end{tabular}

Three different iso-caloric feeds denoted by $\mathrm{A}, \mathrm{B}$ and $\mathrm{C}$ were prepared by mixing the ingredients in various combinations so as to give three different protein levels, viz, 30\%, 35\% and $40 \%$. The protein level of $30 \%, 35 \%$ and $40 \%$ were maintained by various combinations of the ingredients in such a manner that the total metabolizable energy per $100 \mathrm{gm}$ of feeds was about $300 \mathrm{Kcal}$ (Table 2). The energy content of the feeds was calculated on the basis of $4.0 \mathrm{Kcal} / \mathrm{g}$ carbohydrates, $4.0 \mathrm{Kcal} / \mathrm{g}$ proteins and $9.0 \mathrm{Kcal} / \mathrm{g}$ lipids (Pike and Brown, 1967). The feeds were made into pellets by adding the starch liquid and dried in oven at $45^{\circ} \mathrm{C}$ for two days.

Table 2. Composition of fish feed at different protein level

\begin{tabular}{|l|c|c|c|c|c|c|}
\hline \multirow{2}{*}{ Name of ingredients } & \multicolumn{2}{|c|}{$\begin{array}{c}\text { Feed A at 30\% Protein } \\
\text { level }\end{array}$} & \multicolumn{2}{c|}{$\begin{array}{c}\text { Feed B at 35\% protein } \\
\text { level }\end{array}$} & \multicolumn{2}{c|}{$\begin{array}{c}\text { Feed C at 40\% protein } \\
\text { level }\end{array}$} \\
\cline { 2 - 7 } & $\begin{array}{c}\text { Weight in } \\
\text { gm of feeds }\end{array}$ & $\begin{array}{c}\text { Total } \\
\text { protein in } \\
\text { feed (gm) }\end{array}$ & $\begin{array}{c}\text { Weight in } \\
\text { gm of feeds }\end{array}$ & $\begin{array}{c}\text { Total } \\
\text { protein in } \\
\text { feed (gm) }\end{array}$ & $\begin{array}{c}\text { Weight in } \\
\text { gm of feeds }\end{array}$ & $\begin{array}{c}\text { Total } \\
\text { protein in } \\
\text { feed (gm) }\end{array}$ \\
\hline Fish meal & 34.00 & 20.80 & 43.80 & 26.80 & 54.00 & 33.04 \\
\hline Mustard oil cake & 14.50 & 3.91 & 15.00 & 4.05 & 14.00 & 3.78 \\
\hline Rice bran & 49.00 & 5.29 & 38.70 & 4.16 & 24.50 & 3.18 \\
\hline Starch & 2.00 & - & 2.00 & - & 2.00 & - \\
\hline Vitamin premix & 0.50 & - & 0.50 & - & 0.50 & - \\
\hline
\end{tabular}

For rearing of the $M$. gulio brood the ponds were prepared by draining out of water and application of lime to the pond bottom at the rate of $250 \mathrm{~kg} / \mathrm{ha}$. After seven days of liming the pond was filled up (about one meter) with tidal water of the nearby the Shibsha river and after seven days cow dung was applied @ 750kg/ha. After four days, inorganic fertilizer (TSP $25 \mathrm{~kg} / \mathrm{ha}$ and urea $20 \mathrm{~kg} / \mathrm{ha}$ ) were applied.

M. gulio fishes having initial body wt. of $40.3 \pm 1.15 \mathrm{gm}$ were collected from natural sources of brackishwater environment and stocked (male: female 1:1) in the earthen ponds @ 80 individual/ decimal. The experiment was conducted for 140 days in six earthen ponds of 3.5 decimal each. The experimental specimens were divided randomly into three treatments groups A, B, and C, each having $280 \mathrm{M}$. gulio equally divided into three replications. The fishes were fed twice a day @ 5-6\% body weight using the prepared feeds, as per the experimental design. 
Gain in length and weight and development of maturity were monitored and recorded periodically. To identify GSI value and maturity of $M$. gulio, fishes of different feeding trials were collected and data on different parameters of male and female $(n=30)$ were recorded and analyzed. GSI values were estimated as the ratio of the wet gonad weight to somatic weight expressed in percentage by using the following formula:

$$
\text { GSI }=\frac{\text { Weight of gonad }}{\text { Weight of fish }} \times 100
$$

One way analysis of variance (ANOVA) was performed on the yield data to determine treatment effects. Duncan's New Multiple Range Test (Gomez and Gomez, 1984) was used to compare the differences of means.

\section{Results and Discussion}

The overall water quality parameters of ponds in different months are presented in Table 3. The values of water quality parameters in different months were: temperature $24.66 \pm 0.45$ to $31.33 \pm 0.74^{\circ} \mathrm{C}$, dissolved oxygen (DO) $5.32 \pm 0.98$ to $7.95 \pm 0.52 \mathrm{mg} / \mathrm{l}$, alkalinity $160.0 \pm 11.20$ to $182.50 \pm 12.30 \mathrm{mg} / \mathrm{l}$ and salinity $8.30 \pm 1.22 \mathrm{ppt}$ to $8.60 \pm 0.50 \mathrm{ppt}$.

Table 3. Mean value ( $\pm S D)$ of water quality parameters in different months

\begin{tabular}{|c|c|c|c|c|c|}
\hline Month & $\begin{array}{c}\text { Water temperature } \\
\left({ }^{0} \mathrm{C}\right)\end{array}$ & $\mathrm{pH}$ & $\begin{array}{c}\text { Dissolve oxygen } \\
(\mathrm{mg} / \mathrm{L})\end{array}$ & $\begin{array}{c}\text { Total Alkalinity } \\
(\mathrm{mg} / \mathrm{L})\end{array}$ & Salinity (ppt) \\
\hline February & $24.66 \pm 0.45$ & $7.55 \pm 0.58$ & $5.64 \pm 0.86$ & $160.0 \pm 11.20$ & $8.30 \pm 1.22$ \\
\hline March & $25.57 \pm 0.12$ & $7.43 \pm 0.31$ & $7.95 \pm 0.52$ & $182.50 \pm 12.30$ & $8.65 \pm 1.10$ \\
\hline April & $28.40 \pm 0.69$ & $7.59 \pm 0.56$ & $7.05 \pm 0.43$ & $176.20 \pm 15.30$ & $8.50 \pm 1.38$ \\
\hline May & $30.60 \pm 0.57$ & $7.94 \pm 0.51$ & $5.38 \pm 1.12$ & $179.30 \pm 9.86$ & $8.70 \pm 0.32$ \\
\hline June & $31.33 \pm 0.74$ & $7.63 \pm 0.21$ & $5.32 \pm 0.98$ & $176.78 \pm 10.98$ & $8.60 \pm 0.50$ \\
\hline
\end{tabular}

Water temperature influences the physico-chemical and biological factors of a water body. The ranges of mean value of water temperature in different months in the present study were $24.66-31.33^{\circ} \mathrm{C}$. These values are more or less similar to that reported by Paul (1998), Rahman (1999), Kohinoor (2000) and Kohinoor et al (2004). The pH in all ponds water was alkaline throughout the experimental period. Different authors have reported a wide variation in $\mathrm{pH}$ from 6.7 to 8.3 (Hossain et al. 1997), 7.18 to 7.24 (Kohinoor et al. 1998), and 7.37 to 8.65 (Kohinoor et al. 2004) in fertilized fish ponds and found the ranges productive. The ranges and mean values of $\mathrm{pH}$ in the present study were alkaline indicating the productive nature of the fertilized ponds.

The ranges of mean value of dissolved oxygen concentrations were found from $5.32 \pm 0.98$ to $7.95 \pm 0.52 \mathrm{mg} / \mathrm{L}$ which is similar to findings reported by several researchers (Ali et al. 1982; Martyshew, 1983; Rahman, 2000; Kohinoor, 2000 and Kohinoor et al. 2004). Total alkalinity more than $100 \mathrm{mg} / \mathrm{L}$ should be present in high productive water bodies (Alikunhi, 1957). Paul (1998), Kohinoor (2000), Grag and Bhatnagar (2000) and Kohinoor et al (2004) found the average total alkalinity values above $100 \mathrm{mg} / \mathrm{L}$ in their experiments. The total alkalinity values found in the present study were within the suitable range.

The overall growth performance of $M$. gulio brood fed with feeds of different levels of dietary protein is presented in Table 4. Final growth attained under Feed-A (30\% protein), Feed-B (35\% protein) and Feed-C (40\% protein) were $78.47 \pm 2.43,86.58 \pm 3.26$ and $105.37 \pm 8.16 \mathrm{~g}$, respectively. The highest growth was obtained in Feed-C (40\% protein) and lowest in Feed-A $(30 \%$ protein). The final weight showed significant difference $(p<0.05)$ in Feed-C $(40 \%$ protein) followed by Feed-B (35\% protein) and Feed-A (30\% protein) when ANOVA was performed. Absolute growth and absolute growth rate were higher in Feed-C compared to both the feeds A and B. Specific growth rate was also higher in Feed-C $(0.69 \pm 0.05)$ followed 
by feed-B and Feed-A. From the results of growth it is clear that the Feed-C is better than the Feed-B followed by the Feed-A i.e. increase in weight in fish is directly related with the increase in protein levels in feed which is similar to the experimental results reported for chinok salmon (De Long et al. 1958), common carp (Ogino and Saito, 1970), rainbow trout (Saitia, 1974), Clarias batrachus (Sanaullah et al. 1986 and Rahman et al. 1987).

Table 4. Growth performance of $M$. gulio brood fed with feeds of different levels of dietary protein

\begin{tabular}{|l|c|c|c|c|c|}
\hline \multicolumn{1}{|c|}{ Treatments } & $\begin{array}{c}\text { Mean initial } \\
\text { weight }(\mathrm{g})\end{array}$ & $\begin{array}{c}\text { Mean final } \\
\text { weight }(\mathrm{g})\end{array}$ & $\begin{array}{c}\text { Absolute } \\
\text { growth }(\mathrm{g})\end{array}$ & $\begin{array}{c}\text { Absolute growth } \\
\text { rate }(\mathrm{g})\end{array}$ & $\begin{array}{c}\text { Specific growth } \\
\text { rate }(\%)\end{array}$ \\
\hline Feed-A (30\% protein) & $40.3 \pm 1.15$ & $78.47 \pm 2.43^{\mathrm{c}}$ & $38.17 \pm 2.42$ & $0.27 \pm 0.02$ & $0.48 \pm 0.02^{\mathrm{c}}$ \\
\hline Feed-B (35\% protein) & $40.3 \pm 1.15$ & $86.58 \pm 3.26^{\mathrm{b}}$ & $46.28 \pm 3.26$ & $0.33 \pm 0.02$ & $0.55 \pm 0.02^{\mathrm{b}}$ \\
\hline Feed-C (40\% protein) & $40.3 \pm 1.15$ & $105.37 \pm 8.16^{\mathrm{a}}$ & $65.07 \pm 8.16$ & $0.46 \pm 0.06$ & $0.69 \pm 0.05^{\mathrm{a}}$ \\
\hline
\end{tabular}

Figures in the same column having the different superscripts are significantly different $(P<0.05)$

Gonado-somatic index is a very important parameter for understanding gonad development of fish. The gonadosomatic index values (GSI) of $M$. gulio of different feeds are shown in Fig. 1. From the Fig. 1 it is observed that the gonadosomatic index values of both male and female were higher in Feed-C (40\% protein). The average values of gonadosomatic index values for male in Feed-A, in Feed-B and in Feed-C were 2.75, 3.0 and 3.13 respectively. The gonadosomatic index values for female were also higher in Feed-C compared to the other two feeds. There was significant differences $(P<0.05)$ between the gonadosomatic index values of $M$. gulio fed on different dietary protein levels. This is an agreement with the results obtained by Mollah et al. (2003) where $40 \%$ protein level in the feed gave the better gonadosomatic index values in case of $H$. fossilis. Female dwarf gourami and Nile tilapia fed on $35 \%$ protein diets recorded highest ovary weight and gonadosomatic index (Shim et al. 1989; Santiago et al. 1985). Pathmasothy (1985) recorded larger ovaries and higher gonadosomatic index values of $L$. hoevenii fed diets containing 32 and $40 \%$ protein than diet with $24 \%$ protein which is similar to the present study.

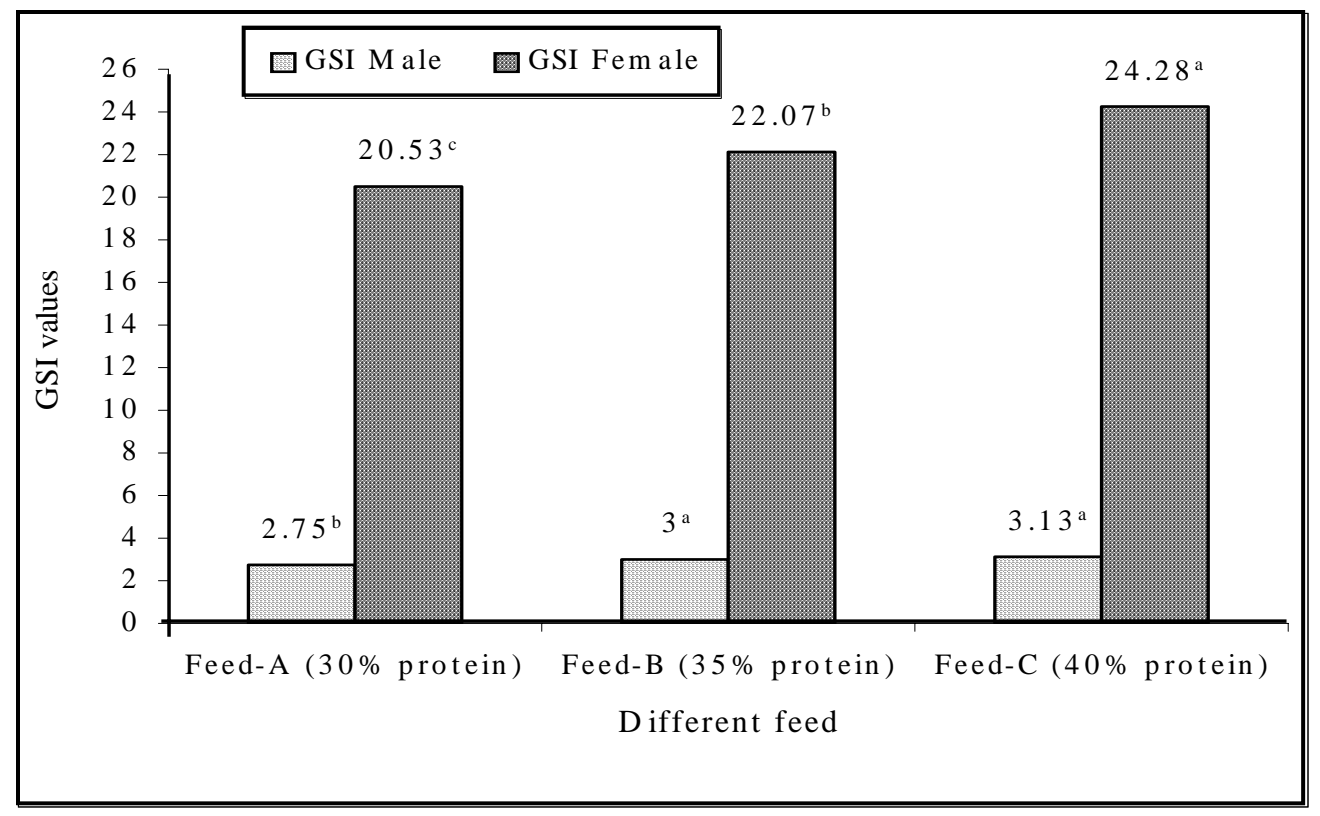

Fig.1. Effect of different dietary protein levels on the maturation of M. gulio. Bars with same color having different letters are significantly different $(P<0.05)$ 
In the present research work, growth performance and maturation of $M$. gulio were studied. Somatic growth and gonado-somatic index were highest in the fish provided with $40 \%$ dietary protein in the feed. Though protein has a positive impact on the growth performance and gonad development of $M$. gulio and other fish species, the present research is probably the first ever work of its nature in Bangladesh. Therefore, the preliminary success obtained through this work can serve as an important base for future research on this point.

\section{References}

Alam, M.J., Begum, M., Islam, M.A. and Pal, H.K. 2006a. Induced spawning and fry production of nona tengra, Mystus gulio (Hamilton.). Progress. Agric., 17 (1): 235-238.

Alam, M.J., Begum, M., Islam, M.A. and Pal, H.K. 2006b. Spawning behavior and induced breeding of an esturine catfish, Mystus gulio (Ham.). Bangladesh J. Fish. Res., 10 (2): 101-109.

Ali, S., Ataur Rahman, A.K., Patwary, A.R. and Islam, K.H.R. 1982. Studies on the diurnal variations in physicochemical factors and zooplankton in a freshwater pond. Bangladesh J. Fish., 2-5(1-2): 15-23.

Alikunhi, K.H. 1957. Fish culture in India. Fm. Bull. Indian Coun. Agri. Res., 20: 144pp.

AOAC. 1980. Official methods of analysis of the Association of Official Analytical Chemists, $13^{\text {th }}$ edition, Washington, D. C. $1018 \mathrm{pp}$.

David, A. 1963. Sexual dimorphism, fecundity and food of the estuarine bagrid, Mystus gulio (Ham.). Proc. Nat. Acad. Sci. India, 33(3): 385-410.

De Long, D.C., Halver, J.E. and Martz, E.T. 1958. Protein requirements of Chinok salmon at two temperatures. J. Nutr., 65: 589-599.

Gomez, K.A. and Gomez, A.A. 1984. Statistcal Procedures for Agricultural Research. $2^{\text {nd }}$ ed. John Wiley and Sons. New York, 640pp.

Grag, S.K. and Bhatnagar, A. 2000. Effect of fertilization on pond productivity and fish biomass in still water ponds stocked with Cirrhinus mrigala (Ham.). Aquaculture Res., 31: 409-414.

Hossain, M.A., Rahmatullah, S.M., Islam, M.S., Kabir, A.K.M.A. and Dewan, S. 1997. Impact of chapila (Gadusia chapra Ham.) on growth of carps in polyculture. Bangladesh J. Fish. Res., 1(2): 19-23.

Islam, M.A., Begum, M., Alam, M.J., Pal, H.K. and Shah, M.M.R. 2007. Growth and survival of esturine cat fish, Mystus gulio (Ham.) larvae fed on live and prepared feeds. Bangladesh J. Zool., 35 (2): 325-330.

Jhingran, V.G. and Natarajan, A.V. 1969. A study of the fisheries and fish populations of the Chilka Lake during the period 1957-65. J. Inland Fish. Soc. India, 1: 49-126.

Kaliyamurthy, M. 1981. Spawning biology of Mystus gulio in lake Pulicat, India. Indian J. Fish., 8(1 \& 2): 36-40.

Kohinoor, A.H.M. 2000. Development of culture technology of three small indigenous fish-mola (Amblypharyngodon mola), punti (Puntius sophore) and chela (Chela cachius) with notes on some aspects of their biology. Ph.D. Thesis. Department of Fisheries Management, Bangladesh Agricultural University, Mymensingh.

Kohinoor, A.H.M., Islam, M.L., Wahab, M.A. and Thilsted, S.H. 1998. Effect of mola (Amblypharyngodon mola) on growth and production of carp in polyculture. Bangladesh J. Fish., 2(2): 119-126.

Kohinoor, A.H.M., Momtaz Begum and Hussain, M.G. 2004. Culture potentials of gulsha (Mystus cavasius) in monoculture management under different stocking densities. Bangladesh J. Fish. Res., 8(2): 95-100.

Martyshew, F.G. 1983. Pond Fisheries. Amerind Publishing Co. Pvt. Ltd., New Delhi, India, 29p.

Mollah, M.F.A., Sarder, M.R.I and Begum, T. 2003. Effects of different dietary levels of vitamin E on the breeding performance of Heteroneustes fosslis (Bloch). Bangladesh J. Fish. Res., 7(1): 11-20.

Ogino, C. and Saito, K. 1970. The utilization of dietary protein by young carp. Bull. Jap. Soc. Sci. Fish., 36: 250-254.

Pandian, T.J. 1966. Feeding and reproductive cycle of the fish Mystus gulio in the Cooum backwaters, Madras. Indian J. Fish., 13(1\&2): 322-333.

Pathmasothy, S. 1985. The effect of three diets with variable protein levels on ovary development and fecundity in Leptobarbus hoevenii. In: Fish Nutrition Research in Asia (Ed C. Y. Cho), I.D.R.C., Ottawa, p. 107-112. 
Paul, S. 1998. Comparison between carp polyculture system with silver carp (Hypopthalmicthys molitrix) and with small indigenous fish mola (Amblypharyngodon mola). M.S. Dissertation, Department of Fisheries Management, Bangladesh Agricultural University, Mymensingh. 85pp.

Pike, R.L. and Brown, M.L. 1967. Nutrition and Integrated Approach. John Wiley and Sons. Inc: New York, 542 pp.

Rahman, M.M. 1999. Effects of species composition on pond ecology and growth of fish in Carp-SIS polyculture systems. M.S. Dissertation, Department of Fisheries Management, Bangladesh Agricultural University, Mymensingh. 92pp.

Rahman, M.A., Gheyasuddin, S., Mazid, M.A., Zaher, M. and Hossain, M.A. 1987. Formulation of quality fish feeds from indigenous raw materials for intensive culture of catfish (Clarias batrachus Linn.). Bangladesh $\mathrm{J}$. Fish., 10(1): 59-66.

Saitia, B.P. 1974. Quantitative protein requirement of rainbow trout. Prog. Fish Cult., 36: 80-85.

Sanaullah, A.A.S.M., Mazid, M.A., Rahman, M.M., Gheyasuddin, S. and Chakroborty, S.C. 1986. Formulation of quality fish feed from indigenous raw materials and their effects on the growth of catfish, Clarias batrachus. Bangladesh J. Fish., 9(1-2): 39-46.

Santiago, C.B., Aldaba, M.B., Abun, E.F. and Larone, M.A. 1985. The effect of artificial diets on fry production and growth of Oreochromis niloticus breeders. Aquaculture, 47:193-203.

Sarker, P.K., Pal, H.K., and Rahman, M.M. 2002. Observation on the fecundity and gonado-somatic index of Mystus gulio in brackishwater of Bangladesh. Online J. Biol. Sci., 2(4): 235-237.

Shim K.F., Landesman, L. and Lam, T.J. 1989. Effect of dietary protein on growth, ovarian development and fecundity in dwarf gourami, Colisa lalia (Hamilton). Journal of Aquaculture in the Tropics, 4:111-123. 